\title{
PENERAPAN MODEL TEAMS GAMES TOURNAMENT UNTUK MENINGKATKAN HASIL BELAJAR SISWA DALAM PERMAINAN BOLA BASKET DI KELAS V SD NEGERI 166492 TEBING TINGGI
}

\author{
Adi Armanyah \\ Guru SD Negeri 166492 Kota Tebing Tinggi \\ Email: adi18@yahoo.co.id
}

\begin{abstract}
Abstrak
Penelitian ini dilatarbelakangi oleh rendahnya persentase ketercapaian atas Kriteria Ketuntasan Minimal (KKM) yang diperoleh siswa kelas V SD Negeri 166492 Kota Tebing Tinggi dari jumlah siswa 28 orang yang mengikuti ulangan harian pada materi pelajaran permainan bola basket. Adapun hasil PTK ini adalah pembelajaran dengan metode Kooperatif model Teams Games Tournament dengan peningkatannya dapat dilihat melaui 2 siklus . Yaitu Kegiatan awal yang tuntas sebanyak 10 orang ( $36 \%$ ), Siklus I sebanyak 15 orang ( $36 \%$ ), Siklus II sebanyak 21 orang ( $75 \%$ ). Hasil pelaksanaan penelitian tindakan kelas yang berlangsung dalam 2 siklus menggunakan Model Teams Games Tournament dalam pembelajaran pendidikan jasmani dan kesehatan pada permainan bola basket ternyata sudah cukup efektif terhadap peningkatan hasil belajar siswa.
\end{abstract}

Kata Kunci : Kooperatif Tipe Teams Games Tournament (TGT)

\section{PENDAHULUAN}

Pendidikan merupakan salah satu masalah yang sangat penting dalam kehidupan manusia, karena melalui pendidikan akan dapat menciptakan manusia yang berpotensi, kreatif dan memiliki ide yang cemerlang sebagai bekal untuk memperoleh masa depan yang lebih baik. Pendidikan merupakan salah satu usaha untuk meningkatkan sumber daya manusia dalam menyesuaikan diri dengan perkembangan ilmu pengetahuan dan teknologi. Peranan seorang Guru sangat penting dalam menentukan kuantitas dan kualitas pengajaran yang dilaksanakan. Oleh sebab itu, Guru harus memikirkan dan membuat perencanaan secara seksama untuk meningkatkan kesempatan belajar bagi siswanya dan memperbaiki kualitas mengajarnya. Guru dapat memotivasi siswa untuk melatih teknik bermain bola basket pada pelajaran penjaskes melalui media yang ada disekitar mereka misalnya televisi, internet atau buku-buku cerita yang mudah dipahami oleh siswa.Pada mata pelajaran penjaskes seharusnya juga memiliki nilai dan karakteristik tertentu yang mendasari materi pelajaran penjaskes tersebut. Dalam rangka peningkatan hasil belajar Penjaskes dengan pendekatan pembelajaran efektif, efisien dan terpadu disesuaikan dengan proses dan kemampuan siswa diantaranya dengan mengadopsi model pembelajaran Teams Games Tournament. Berdasarkan uraian pada latar belakang di atas, dapat 
diidentifikasikan

beberapa

permasalahan sebagai berikut :

a. Guru monoton sehingga kondisi dikelas membosankan

b. Guru hanya menggunakan alat peraga yang sudah jadi

c. Guru kurang Kreatif

d. Siswa kurang memahami pelajaran yang diberikan

Berdasarkan uraian pada latar belakang masalah, maka dapat dirumuskan permasalahan sebagai berikut. " Apakah melalui model pembelajaran Teams Games Tournament pada materi pelajaran penjaskes, hasil belajar siswa pada permainan bola basket kelas V SD Negeri 166492 Tebing Tinggi dapat meningkat?"

\section{Tujuan Penelitian}

Tujuan Umum

Agar dapat mengkongkritkan pembelajaran dan dapat melibatkan siswa dalam pembelajaran penjaskes sehingga pembelajaran lebih bermakna bagi siswa.

Tujuan Khusus

Untuk mengetahui apakah dengan menggunakan model pembelajaran teams games tornament dalam pembelajaran penjaskes dapat meningkatkan hasil belajar siswa.

\section{Manfaat Penelitian}

Bagi Siswa

a. Membantu siswa lebih memahami konsep materi bangun ruang sisi datar.

b. Meningkatkan prestasi belajar penjaskes siswa. c. Menciptakan pembelajaran penjaskes yang kreatif dan menyenangkan

\section{Manfaat Bagi Guru}

a. Meningkatkan kualitas guru dalam melaksanakan tugas mengajar.

b. Merangsang guru-guru yang lain untuk melakukan pembelajaran yang kreatif dan menyenangkan bagi siswa.

Manfaat Bagi Sekolah

a. Meningkatkan prestasi belajar para siswa SD Negeri 166492

b. Agar SD Negeri 166492 Kota Tebing Tinggi mampu bersaing dengan SD yang lain dalam hal inovasi di dalam pembelajaran.

\section{TINJAUAN TEORI}

\section{Hakikat Pembelajaran Kooperatif}

Model pembelajaran dapat diartikan sebagai perencanaan yang berisi tentang rangkaian kegiatan yang didesain untuk mencapai pendidikan tertentu (Sanjaya, 2007 : 126).

\section{Pembelajaran Kooperatif Tipe Teams-Games-Tournaments (TGT)}

Teams Games Tournament (TGT)

TGT adalah salah satu tipe pembelajaran kooperatif yang menempatkan siswa dalam kelompok-kelompok belajar yang beranggotakan 5 sampai 6 orang siswa yang memiliki kemampuan, 
jenis kelamin, suku kata atau ras yang berbeda. Menurut Slavin pembelajaran kooperatif tipe TGT terdiri dari 5 langkah tahapan yaitu : tahap penyajian kelas (class precentation), belajar dalam kelompok (teams), permainan (games), pertandingan (tournament), dan penghargaan kelompok (team recognition). Model pembelajaran kooperatif tipe TGT memiliki ciriciri sebagai berikut :

Siswa Bekerja Dalam KelompokKelompok Kecil
a. Games Tournament
b. Penghargaan kelompok

\section{Kelebihan dari pembelajaran TGT antara lain :}

a. Lebih meningkatkan pencurahan waktu untuk tugas

b. Mengedepankan penerimaan terhadap perbedaan individu

c. Dengan waktu yang sedikit dapat menguasai materi secara mendalam

d. Proses belajar mengajar berlangsung dengan keaktifan dari siswa

e. Mendidik siswa untuk berlatih bersosialisasi dengan orang lain

f. Motivasi belajar lebih tinggi

g. Hasil belajar lebih baik

h. Meningkatkan kebaikan budi, kepekaan dan toleransi

\section{Sedangkan kelemahan TGT adalah:}

Bagi guru

$$
\begin{gathered}
\text { a. Sulitnya pengelompokan } \\
\text { siswa yang mempunyai }
\end{gathered}
$$

kemampuan heterogen dari segi akademis. Kelemahan ini akan dapat diatasi jika guru yang bertindak sebagai pemegang kendali teliti dalam menentukan pembagian kelompok

b. Waktu yang dihabiskan untuk diskusi oleh siswa cukup banyak sehingga melewati waktu yang sudah ditetapkan. Kesulitan ini dapat diatasi jika guru mampu menguasai kelas secara menyeluruh

Bagi siswa

a. Masih adanya siswa berkemampuan tinggi kurang terbiasa dan sulit memberikan penjelasan kepada siswa lainnya. Untuk mengatasi kelemahan ini, tugas guru adalah membimbing dengan baik siswa yang mempunyai kemampuan akademik tinggi agar dapat dan mampu menularkan pengetahuannya kepada siswa yang lain.

\begin{tabular}{|c|c|}
\hline $\begin{array}{l}\text { Dalam } \\
\text { ajaran }\end{array}$ & $\begin{array}{l}\text { konsep } \\
\text { yang }\end{array}$ \\
\hline & urv \\
\hline
\end{tabular}

\section{Kerangka Berfikir} menggunakan metode ceramah dan tanya jawab, serta tidak menggunakan media pembelajaran yang tepat, akibatnya siswa kurang aktif dalam pembelajaran dan minat siswa terhadap mata pelajaran Penjaskes juga menjadi rendah. Aktivitas yang dilakukan siswa pada proses pembelajaran terbatas 
pada mendengarkan penjelasan guru, mencatat, mengerjakan soal-soal. Akibat dari proses pembelajaran seperti terurai diatas maka pemahaman siswa pada permainan bola basket menjadi kurang atau lemah sehingga mengakibatkan prestasi belajar siswa dalam mata pelajaran Penjaskes menjadi rendah..

Berdasarkan permasalahan diatas, peneliti termotivasi untuk mengatasi masalah yang dihadapi siswa dalam proses pembelajaran dikelas khususnya dalam memahami konsep permainan bpla basket pada mata pelajaran penjaskes di kelas $\mathrm{V}$ SD Negeri 166492 Tebing Tinggi.

Melalui Penelitian Tindakan Kelas yang bertujuan memperbaiki kegiatan pembelajaran di kelas untuk meningkatkan prestasi belajar siswa, peneliti melakukan tindakan awal, tindakan lanjutan sebanyak dua siklus. Tindakan awal menggunakan metode ceramah, siklus I dan II menggunakan model pembelajaran Teams Games Tournament.

Dengan menggunakan model pembelajaran Teams Games Tournament siswa diharapkan dapat bekerjasama, saling membantu mengembangkan potensi diri secara optimal bagi kelompoknya dan belajar memperoleh dan memahami pengetahuan yang dibutuhkan secara langsung, serta melibatkan siswa aktif dalam mengembangkan pengetahuan, sikap, keterampilan dalam suasana belajar yang menyenangkan mereka, sehingga apa yang dipelajari lebih bermakna dan dipahami bagi diri setiap siswa .
Oleh karena itu diharapkan melalui model Teams Games Tournament dapat meningkatkan prestasi belajar dan pemahaman siswa pada permainan bola basket di SD Negeri 166492 Kota Tebing Tinggi.

\section{Hipotesis Tindakan}

Menurut Winarno Surachmad (1982) bahwa: "Hipotesa adalah sebagai sebuah kesimpulan, tetapi kesimpulan ini belum final masih harus dibuktikan kebenarannya. Hipotesa adalah jawaban dugaan yang dianggap besar kemungkinannya untuk menjadi jawaban yang benar".

Dari kutipan uraian diatas peneliti membuat dugaan atau hipotesis tindakan dalam penelitian yang dilaksanakan di kelas V SD Negeri 166492 Kota Tebing Tinggi, yaitu : Melalui penerapan model pembelajaran teams games tournament kemampuan siswa dalam memahami permainan bola basket dan prestasi belajar pada pelajaran penjaskes dapat ditingkatkan.

\section{METODOLOGI PENELITIAN Tempat Penelitian}

Tempat penelitian adalah tempat yang digunakan dalam melakukan penelitian untuk memperoleh data yang diinginkan. Penelitian ini bertempat di SD Negeri 166492 Tebing Tinggi Tahun Pelajaran 2012/2013. SD Negeri 166492 berada di jalan Ir. H Juanda Kelurahan Tanjung Marulak Kecamatan Rambutan. 


\section{Waktu Penelitian}

Waktu penelitian adalah waktu berlangsungnya penelitian atau saat penelitian ini dilangsungkan. Penelitian ini dilaksanakan pada bulan Januari Maret 2013.

\section{Subyek Penelitian}

Subyek penelitian adalah siswa-siswi Kelas V SD Negeri 166492 Tebing Tinggi Tahun Pelajaran 2012/2013. Dengan keadaan siswa dalam kelas berjumlah 28 Siswa dimana Laki-laki berjumlah 14 Orang dan perempuan berjumlah 14 Orang.

\section{Prosedur Penelitian}

Penelitian ini menggunakan model penelitian tindakan dari Kemmis dan Taggart (dalam Sugiarti, 1997: 6), yaitu berbentuk spiral dari siklus yang satu ke siklus yang berikutnya. Setiap siklus meliputi planning (rencana), action (tindakan), observation (pengamatan), dan reflection (refleksi).

\section{Teknik Analisis Data}

Untuk mengalisis tingkat keberhasilan atau persentase keberhasilan siswa setelah proses belajar mengajar setiap putarannya dilakukan dengan cara memberikan evaluasi berupa soal tes tertulis pada setiap akhir putaran. Analisis ini dihitung dengan menggunakan statistik sederhana yaitu:
Untuk menilai ulangan atau tes formatif

Peneliti melakukan penjumlahan nilai yang diperoleh siswa, yang selanjutnya dibagi dengan jumlah siswa yang ada di kelas tersebut sehingga diperoleh rata-rata tes formatif dapat dirumuskan:

$\underline{\text { Rumus : }}$

$$
\bar{X}=\frac{\sum X}{\sum N}
$$

$$
\begin{aligned}
\bar{X} & =\text { Nilai rata-rata } \\
\Sigma \mathrm{X} & =\text { Jumlah semua nilai siswa } \\
\Sigma \mathrm{N} & =\text { Jumlah siswa }
\end{aligned}
$$

\section{Untuk ketuntasan belajar}

Ada dua kategori ketuntasan belajar yaitu secara perorangan dan secara klasikal. Berdasarkan petunju pelaksanaan belajar mengajar kurikulum 1994 (Depdikbud, 1994), yaitu seorang siswa telah tuntas belajar bila telah mencapai skor $65 \%$ atau nilai 65 , dan kelas disebut tuntas belajar bila di kelas tersebut terdapat $85 \%$ yang telah mencapai daya serap lebih dari atau sama dengan $65 \%$. Untuk menghitung persentase ketuntasan belajar digunakan rumus sebagai berikut:

$$
P=\frac{\sum \text { Siswa.yang.tuntas.belajar }}{\sum \text { Siswa }} \times 100 \%
$$


Untuk lembar observasi

a. Lembar observasi pengelola metode pembelajarn koooperatif model Meninjau Ulang.Untuk menghitung lembar observasi pengelolaan metode pembelajaran kooperatif model Meninjau Ulang digunakan rumus sebagai berikut :

$$
\overline{\mathrm{X}}=\frac{P 1+P 2}{2}
$$

Dimana P1 = Pengamat 1 dan

$$
\mathrm{P} 2 \text { = Pengamat } 2
$$

b. Lembar observasi aktifitas guru dan siswa Untuk menghitung lembar observasi aktifitas guru dan siswa digunakan rumus sebagai berikut :

$$
\%=\frac{\bar{x}}{\Sigma x} \mathrm{x} 100 \% \text { dengan }
$$

$$
\begin{aligned}
\mathrm{X}= & \frac{\text { Jumāh.hasil.pengama } \tan }{\text { Jumlah.pengama } \tan }= \\
& \frac{P 1+P 2}{2}
\end{aligned}
$$

Dimana: $\%=$ Presentase pengamatan

$$
\begin{aligned}
\mathrm{X} & =\text { Rata-rata } \\
\sum \mathrm{x} & =\text { Jumlah } \overline{\text { rata-rata }} \\
\mathrm{P} 1 & =\text { Pengamat } 1 \\
\mathrm{P} 2 & =\text { Pengamat } 2
\end{aligned}
$$

\section{HASIL PENELITIAN DAN PEMBAHASAN}

Untuk mengetahui hasil penelitian, langkah pertama yang dilakukan peneliti adalah mengidentifikasi masalah melalui pengamatan proses belajar mengajar yakni rendahnya kemampuan siswa dalam permainan bola basket pada mata pelajaran penjaskes, sehingga mempengaruhi nilai ketuntasan dan prestasi belajar siswa di kelas V SD Negeri 166492 Tebing Tinggi yang berjumlah 28 siswa.

Proses pengamatan dilakukan dengan menggunakan daftar chek dan catatan lapangan. Pengkategorian untuk analisis data hasil belajar siswa adalah sebagai berikut :

Tabel 4.1 Pengkategorian Nilai Siswa

\begin{tabular}{|l|l|}
\hline \multicolumn{1}{|c|}{ Nilai siswa } & $\begin{array}{c}\text { Klasifikasi } \\
\text { Nilai }\end{array}$ \\
\hline $80-100$ & Sangat baik \\
\hline $66-79$ & Baik \\
\hline $56-65$ & Cukup \\
\hline $40-55$ & Kurang \\
\hline$>40$ & Gagal \\
\hline
\end{tabular}


Minat Belajar Siswa terhadap materi ajar Permainan bola basket

Data yang diperoleh melalui hasil observasi pada kondisi awal , menunjukkan banyaknya jumlah siswa senang belajar dengan menggunakan model ceramah pada Permainan bola basket sangat tidak setuju $28 \%$, tidak setuju $22 \%$ dan setuju 25\% lebih besar persentase tidak setuju dan sangat tidak setuju.berarti siswa lebih menyenangi belajar dengan Guru memakai model yang lain.

Siswa mayoritas tidak setuju (22 \%) bahwa Permainan bola basket mudah dipahami dengan menggunakan model ceramah. Siswa yang setuju dengan model ceramah (25\%), namun yang Sangat Tidak Setuju berjumlah 8 orang ( $28 \%$ ). Keadaan ini membuktikan bahwa lebih dari $50 \%$ siswa sudah menginginkan model pembelajaran yang baru dari selama ini yang dipakai oleh Guru yaitu ceramah dan penugasan.

\section{Hasil Siklus Pertama}

Sebanyak 14 orang (50 \%) siswa menyatakan bahwa dengan model ceramah yang dilakukan Guru selama ini membuat mereka kejenuhan dalam mengikuti proses pembelajaran .

Mereka tidak dapat berinteraksi dengan teman selama kegiatan belajar mengajar, sehingga siswa hanya bersifat pasif saja mengikuti proses pembelajaran berlangsung.
Siklus pertama terdiri dari 4 tahap kegiatan, yakni kegiatan perencanaan, kegiatan pelaksanaan, kegiatan observasi dan kegiatan refleksi.

Data yang diperoleh melalui hasil observasi pada kondisi awal , dari tabel diatas memperlihatkan banyaknya jumlah siswa yang termasuk dalam kategori Kurang untuk mengajukan pertanyaan ( 14 $\%$ ), Cukup $25 \%$. Secara keseluruhan sebanyak 11 siswa dari 28 siswa (menjadi sampel) yang termasuk dalam kategori tidak mampu memberi pertanyaan. Kategori tidak mampu disini berdasarkan analisis peneliti dan kedua observer adalah siswa tidak dapat merumuskan pertanyaannya dengan baik. Selain itu juga yang termasuk kategori Kurang adalah di dalamnya termasuk siswa yang tidak memberikan pertanyaan sama sekali pada waktu proses pembelajaran berlangsung. Hanya 17 orang siswa yang dapat mengajukan pertanyaan termasuk kategori Sangat Baik (7 orang) dan Baik (10 orang ).

Demikian juga halnya dengan siswa yang memiliki kemampuan untuk Menanggapi Pertanyaan, mayoritas juga termasuk dalam kategori Cukup (18\%) dan Kurang (32\%). Sedangkan yang termasuk dalam kategori Baik hanya 9 orang dan kategori Sangat Baik hanya 5 orang saja. Keadaan ini tentunya menimbulkan keprihatinan bahwasanya selama ini siswa enggan untuk mengungkapkan pertanyaan tentang materi ajar yang diberikan 
kepadanya. Ada beberapa faktor penyebab yang mungkin mendasari hal ini diantaranya ialah : iklim belajar yang tidak memberi ruang kepada siswa untuk berperan aktif dalam proses pembelajaran. Selama ini Guru sangat dominan di dalam kelas sehingga siswa hanya dapat mendengarkan saja dengan tekun.

Pada Siklus Pertama ini, model pembelajaran Teams Games Tournament ini sudah mulai diterapkan dimana essensi dari model ini adalah terjalinnya kerjasama siswa yang berada dalam kelompok. Hasil Observasi ternyata mayoritas siswa hanya termasuk dalam ketegori Cukup, yaitu sejumlah 10 siswa ( $36 \%$ ) untuk bekerjasama dalam mengerjakan tugas kelompok. Demikian juga dengan kemampuan siswa untuk mempresentasikan hasil kerja kelompok juga mayoritas siswa (36\%) termasuk dalam kategori Cukup dan $28 \%$ termasuk dalam kategori Kurang. Keadaan ini memprihatinkan karena siswa ternyata belum memiliki kemampuan untuk bekerjasama dengan baik dalam kelompok. Hal ini terjadi karena selama ini, siswa tidak dibiasakan untuk melakukan diskusi bersama teman-temannya.

Sejalan dengan itu juga, kemampuan siswa untuk menarik kesimpulan juga mayoritas hanya mencapai kategori Cukup yaitu 36\% dan ketegori Kurang mencapai $28 \%$. Keadaan ini juga cukup memprihatinkan karena dengan lemahnya siswa dalam menarik kesimpulan hasil diskusi kelompok maka hal ini merefleksikan kemampuan siswa dalam menganalisis suatu hasil diskusi.

Tugas yang diberikan Guru juga tidak dapat diselesaikan dengan tepat waktu. Hal ini terlihat mayoritas siswa $36 \%$ termasuk dalam kategori Cukup dan $15 \%$ termasuk dalam kategori Kurang untuk menyelesaikan tugasnya dengan tepat waktu. Keterlambatan dalam penyelesaian tugas dapat disebabkan oleh berbagai faktor diantaranya siswa tidak memahami materi pelajaran yang diberikan, Guru kurang mampu menjelaskan materi pelajaran dengan baik atau waktu yang diberikan terlalu singkat untuk menyelesaikan tugas yang diberikan kepada siswa. Berdasarkan analisis peneliti dan kedua observer ketiga faktor ini mungkin dapat menjadi penyebab keterlambatan siswa dalam menyelesaikan tugas yang diberikan kepadanya.

Rasa Antusiasme atau semangat untuk mengerjakan tugas yang diberikan oleh Guru juga terlihat rendah dalam diri mayoritas siswa. Hal ini dapat dibuktikan mayoritas siswa $36 \%$ termasuk dalam kategori Cukup dan $18 \%$ termasuk dalam kategori Kurang. Hanya 15 orang siswa saja dari 28 siswa yang termasuk dalam kategori Sangat Baik dan Baik tentang Antusiasme mengerjakan tugas yang diberikan kepadanya.

\section{Hasil Siklus Kedua}

Siklus Kedua dua pertemuan terdiri dari 4 tahap kegiatan, yakni 
kegiatan perencanaan, kegiatan pelaksanaan, kegiatan observasi dan kegiatan refleksi, seperti yang diuraikan berikut ini :

Data yang diperoleh melalui hasil observasi pada Siklus ke 2 ini , dari tabel diatas memperlihatkan semakin banyaknya jumlah siswa yang senang belajar dengan menggunakan model pembelajaran Teams Games Tournament pada Permainan bola basket yaitu Sangat Setuju $61 \%$. Keadaan ini meningkat dari Siklus pertama, dan setuju $28 \%$

Keadaan ini membuktikan siswa lebih menyenangi model pembelajaran Teams Games Tournament.

Pada Siklus ke 2, secara garis besar semua aspek penilaian yang berhubungan dengan minat belajar siswa terhadap materi ajar Permainan bola basket dengan penerapan Model Pembelajaran Teams Games Tournament mengalami peningkatan. Pernyataan siswa " Sangat Tidak Setuju "tentang model pembelajaran ini tidak adak ada lagi. siswa yang menyatakan "Sangat Setuju" meningkat jumlahnya dibandingkan dengan Siklus Pertama. dengan semua aspek penilaian tentang penerapan model pembelajaran ini.

Siswa juga berpendapat bahwa materi pembelajaran Permainan bola basket lebih mudah dipahami dengan model pembelajaran Teams Games Tournament. Hal ini dibuktikan sebanyak $28 \%$ dari 28 siswa menyatakan Setuju dan $611 \%$ menyatakan Sangat Setuju. Selain itu, sebanyak $90 \%$ Siswa juga menyatakan dengan model pembelajaran Teams Games Tournament mereka dapat memahami Permainan bola basket dengan baik.

Siswa juga merasakan dengan penerapan model pembelajaran Teams Games Tournament, Siswa dapat berinteraksi dan berdiskusi dengan teman selama proses pembelajaran berlangsung sehingga tidak menimbulkan kebosanan dalam belajar. Fakta ini didukung oleh 28 orang siswa yang menyatakan Setuju dan Sangat Setuju dengan hal ini.

Menurut siswa ketika proses pembelajaran dengan menggunakan model pembelajaran Teams Games Tournament, Guru terlihat sangat komunikatif dalam membimbing siswa yang mengalami kesulitan dalam belajar. Hal ini dinyatakan oleh $90 \%$ siswa. Selama ini dengan model ceramah, Guru terlihat monoton dan tidak komunikatif dalam menyampaikan materi pelajaran.

Siswa juga berharap mata pelajaran lainnya sebaiknya juga menggunakan model pembelajaran Teams Games Tournament agar dapat meningkatkan partisipasi siswa dalam proses pembelajaran. Keinginan ini disampaikan oleh siswa sebanyak $71 \%$ yang menyatakan Setuju dan Sangat Setuju. Demikian juga halnya dengan mata pelajaran Penjaskes, mayoritas siswa mengharapkan model pembelajaran Teams Games 
Tournament dapat diterapkan pada proses pembelajaran berikutnya. Hal ini dinyatakan oleh mayoritas siswa yaitu $36 \%$ menyatakan Setuju dan $43 \%$ menyatakan Sangat Setuju, sehingga total siswa yang berharap model ini diterapkan pada mata pelajaran Penjaskes adalah sebanyak 22 siswa ( $79 \%$ ) dari 28 siswa.

\section{SIMPULAN DAN SARAN}

\section{Simpulan}

Dari hasil kegiatan
pembelajaran yang telah
dilakukan selama dua siklus, dan
berdasarkan seluruh pembahasan serta analisis yang telah dilakukan dapat disimpulkan sebagai berikut:

a. Pembelajaran dengan model Teams Games Tournament memiliki dampak positif dalam meainan bola basket dapat meningkatkan hasil belajar siswa yang ditandai dengan peningkatan ketuntasan belajar siswa dalam setiap siklus, yaitu kegiatan awal 10 orang (36 $\%$ ), siklus I 15 orang ( $54 \%$ ), siklus II 21 orang $(75 \%)$.

b. Penerapan model Teams Games Tournament pada permainan bola basket pada materi pelajaran penjaskes mempunyai pengaruh positif, yaitu dapat meningkatkan hasil belajar siswa yang ditunjukan dengan rata-rata jawaban siswa yang menyatakan bahwa siswa tertarik dan berminat dengan metode belajar aktif model teams games tournament pada materi pelajaran sehingga mereka menjadi termotivasi untuk belajar.

c. Penerapan model teams games tournament pada permainan bola basket dapat meningktakan hasil belajar siswa dan telah diterima siswa selama ini, sehingga mereka merasa siap untuk menghadapi ujian kenaikan kelas yang segera akan dilaksanakan.

\section{Saran}

Dari hasil penelitian yang diperoleh dari uraian sebelumnya agar proses belajar mengajar Penjaskes lebih efektif dan lebih memberikan hasil yang optimal bagi siswa, maka disampaikan saran sebagai berikut:

a. Untuk melaksanakan metode belajar aktif model teams games tournamnet pada materi pelajaran memerlukan persiapan yang cukup matang, sehingga guru harus mampu menentukan atau memilih topik yang benarbenar bisa diterapkan dengan metode belajar aktif model meninjau kesulitan pada materi pelajaran proses belajar mengajar sehingga diperoleh hasil yang optimal.

b. Dalam rangka meningkatkan hasil belajar siswa, guru hendaknya lebih sering melatih siswa dengan 
berbagai metode, walaupun dalam taraf yang sederhana, dimana siswa nantinya dapat menemukan pengetahuan baru, memperoleh konsep dan keterampilan, sehingga siswa berhasil atau mampu memecahkan masalahmasalah yang dihadapinya.

c. Perlu adanya penelitian yang lebih lanjut, karena hasil penelitian ini hanya dilakukan di Kelas V SD Negeri 166492 Tebing Tinggi Tahun Pelajaran 2012/2013.

\section{DAFTAR RUJUKAN}

Ahmadi, Abu dan Supriyono W. 2004. Psikologi Belajar. Jakarta: Rineka Cipta.

Ali, Muhammad. 1996. Guru Dalam Proses Belajar Mengajar. Bandung: Sinar Baru Algesindon.

Aqib, Zainal. 2009. Penelitian Tindakan Kelas untuk Guru. Bandung: CV. Yrama Widya.

Arikunto, Suharsimi. Dkk., 2006. Penelitian Tindakan Kelas. Jakarta: Bumi Aksara.

Arikunto, Suharsimi. 2002. Prosedur Penelitian Suatu Pendekatan Praktek. Jakarta: Rineksa Cipta.

Arikunto, S. 2002. Dasar-dasar Evaluasi Pendidikan. Jakarta: Bumi Aksara.
Departemen Pendidikan Nasional. 2005. Materi Pelatihan Terintegrasi

Matematika. Jakarta: Depdiknas, Direktorat Jenderal. Pendidikan Dasar dan Menengah, dan Direktorat Pendidikan Lanjutan Pertama.

Dimyati dan Mudjiono. 2002. Belajar dan Pembelajaran. Jakarta: Rineka Cipta.

Hadi, Sutrisno. 1982. Metodologi Research, Jilid 1. Yogyakarta: YP. Fak. Psikologi UGM.

Hadis, Abdul. 2006. Psikologi Dalam Pendidikan.

Bandung: Alfabeta.

Hartutik. 2006. Efektivitas Pembelajaran Biologi SMA dengan Pendekatan Jelajah Alam Sekitar (JAS) berdasar Analisis SWOT dalam kemasan $C D$ Interaktif. Tesis: Program Pascasarjana Prodi Pend. IPA Unnes.

Hudojo, Herman. 1990. Strategi Mengajar Belajar Bahasa Indonesia. IKIP Malang: Malang.

Ibrahim, M. dkk., 2000. Pembelajaran Kooperatif. Surabaya: Unversitas Negeri Surabaya.

Ngalim, Purwanto, M. 1984. PrinsipPrinsip dan Teknik Evaluasi Pengajaran. Bandung: Remaja Rosdakarya. 
Mariyana, Rita. 2005. Strategi Pengelolaan Lingkungan Belajar Di Taman KanakKanak. Jakarta: Departemen Pendidikan Nasional.

Oemar, Hamalik. 2003. Proses Belajar Mengajar. Jakarta: PT. Bumi Aksara.

Pasaribu,I. L. Dkk, 1982. Teori Kepribadian. Bandung: Tarsito.

Riduwan. 2004. Belajar Mudah Penelitian Untuk GuruKaryawan dan Peneliti Pemula. Bandung: Alfabeta.

Roestiyah, N.K. 1989. Masalahmasalah Ilmu Keguruan. Jakarta: Bina Aksara.

Rusyan, Tabrani. dkk, 1994. Pendekatan dalam Proses Belajar Mengajar. Bandung: Remaja Karya.

Sanjaya, Wina. 1991. Pembelajaran Dalam Implementasi Kurikulum Berbasis Kompetensi. Bandung: Kencana.

Simanjuntak, Lisnawaty. Dkk. 1992. Metode Mengajar Matematika 1. Bandung: Rineka Cipta.

Sudjana, Nana. 1989. Penilaian Hasil Proses Belajar Mengajar. Bandung: Remaja Rosdakarya.

Sukmadinata, Nana Syaodih. 2004. Metode Penelitian Pendidikan. Bandung: PT. Remaja Rosdakarya.
1998. Dasar-dasar Proses Belajar Mengajar. Bandung: Sinar Baru Algensindo.

Usman, Moh. Uzer. 1993. Upaya Optimalisasi Kegiatan Belajar Mengajar. Bandung: Remaja Rosdakarya Offset.

Winkel. W.S. 1987. Psikologi Pengajaran. Jakarta: Gramedia.

Wardhani. 2007. Pengertian Belajar. http://www.whandi.net/in dex.php?pilih=news\& $\underline{\text { Mod=yes\&aksi=lihat\&id }}$ =41. (diakses 12 januari 2010).

Yasa, Doantara. 2008. Metode Pembelajaran Kooperatif. http://ipotes.wordpress.co $\underline{\mathrm{m}}$

/2008/05/10metodepembelajaran-kooperatif. (diakses 12 januari 2010 
